\title{
Tripartite Motif Protein 72 Regulates the Proliferation and Migration of Rat Cardiac Fibroblasts via the Transforming Growth Factor- $\beta$ Signaling Pathway
}

\author{
Jianquan Zhao Han Lei \\ Cardiology Department, First Affiliated Hospital of Chongqing Medical University, Chongqing, China
}

\section{Key Words}

Tripartite motif protein 72 . Cardiac fibroblasts .

Proliferation · Migration

\begin{abstract}
Background: The proliferation and migration of cardiac fibroblasts are critical for the progress of cardiac fibrosis. Tripartite motif protein 72 (Trim72), also known as MG53, mediates the dynamic process of membrane fusion and exocytosis in striated muscle. However, the role of Trim72 in the proliferation and migration of cardiac fibroblasts is unknown. Methods: In the present study, we used small interference RNA (siRNA) to silence Trim72 and then investigated the effects of Trim72 on cardiac fibroblast proliferation and migration, which were activated during cardiac remodeling after myocardial infarction. Cardiac fibroblasts were isolated from 2- to 3-day-old neonatal Sprague-Dawley rats and transfected with siRNA. A cell-counting assay was used to determine the proliferation of cardiac fibroblasts. A Boyden chamber assay was performed to determine the migration of cardiac fibroblasts. Results: Our study has, for the first time, demonstrated that Trim72 regulates the cell proliferation and migration of rat cardiac fibroblasts. Furthermore, the data from the gene expression profile microarray analysis indicate that Trim 72 depletion can cause downregulation of the transforming growth factor (TGF)- $\beta$ signaling path-
\end{abstract}

way, suggesting that Trim72 regulates the proliferation and migration of cardiac fibroblasts probably via the TGF- $\beta$ signaling pathway. Conclusions: We have demonstrated that Trim72 might play a pivotal role in the proliferation of neonatal rat cardiac fibroblasts, which could be a potential target for the treatment of cardiac fibrosis. However, the involvement of other signaling pathways and factors in the formation of cardiac fibrosis cannot be excluded.

(c) 2016 S. Karger AG, Basel

\section{Introduction}

The myocardium is mainly composed of the surrounding extracellular matrix (ECM), cardiomyocytes, and cardiac fibroblasts $[1,2]$. Cardiac fibroblasts comprise two thirds of the nonmyocytes and have various functions in both physiological and pathological processes [3-5]. In response to chronic ischemia stimuli, cardiac fibroblasts proliferate, migrate, and excrete ECM to maintain myocardial function. However, if the repair phase is not terminated appropriately, excessive deposition of ECM will result in chronic fibrosis, ultimately leading to worse cardiac function and a poor prognosis [6-8]. During the development of cardiac remodeling after myocardial infarction, the proliferation and migration of cardiac fibroblasts play critical roles in heart failure.

\section{KARGER}

E-Mail karger@karger.com

www.karger.com/crd
(C) 2016 S. Karger AG, Basel

0008-6312/16/1343-0340\$39.50/0
Han Lei, MD

Cardiology Department

First Affiliated Hospital of Chongqing Medical University

1 Yixueyuan Road, Yuzhong District, Chongqing 400016 (China)

E-Mail leihan@cqmu.edu.cn 
Tripartite motif protein 72 (Trim72), also referred to as mitsugumin 53 , is abundantly expressed in muscle [911]. Similarly to other Trim family members, Trim 72 contains a Spry motif, i.e. a conserved RING, at the carboxyl terminus and a coiled coil motif at the $\mathrm{NH} 2$ terminus, which serve to distinguish Trims as specific isoforms. A previous study demonstrated that Trim72 functions as a critical component of the 'cell membrane repair kit' in these tissues [12-14]. In the experiment with Trim72 knockout mice, Trim72 depletion increased contractility tissue damage, which is reduced in older mice subjected to downhill running $[12,15,16]$. A recent study showed that recombinant Trim 72 protein provides therapeutic benefits for skeletal muscle myo-necrosis following damage due to vigorous exercise [17]. Moreover, it has also been shown that Trim72 plays a cardioprotective role following ischemia-reperfusion injury [18]. However, the molecular mechanism of Trim 72 has not yet been extensively studied in cardiac fibroblasts.

In order to investigate the role of Trim72 in the migration and proliferation of cardiac fibroblasts, we, in this study, knocked down Trim72 in rat cardiac fibroblasts to determine whether Trim72 depletion would affect cardiac fibroblast proliferation and migration. In addition, the underlying molecular mechanisms were explored.

\section{Materials and Methods}

Cardiac Fibroblast Isolation and Cell Culture

Cardiac fibroblasts were prepared from 2- to 3-day-old neonatal Sprague-Dawley rats as previously described $[19,20]$. Briefly, an isolated heart was perfused using a Langendorff apparatus and treated with $0.02 \%$ collagenase for $20 \mathrm{~min}$. The heart was minced in Dulbecco's modified Eagle's medium and cultured for $90 \mathrm{~min}$ in a $2 \%$ gelatin-coated culture dish. The floating cells were rinsed and the attached cells were used as cardiac fibroblasts. The cells were cultured in DMEM containing $10 \%$ fetal bovine serum and $1 \%$ penicillin streptomycin Fungizone in a humidified incubator with $5 \% \mathrm{CO}_{2}$ at $37^{\circ} \mathrm{C}$. Cardiac fibroblast cell passages $2-5$ were used. These protocols were approved by the Animal Subject Committee of Chongqing Medical University.

\section{Immunostaining Analysis}

Cardiac fibroblasts were grown on glass coverslips, fixed with ice-cold $4 \%$ paraformaldehyde for $15 \mathrm{~min}$, and blocked with phosphate-buffered saline (PBS) containing 10\% fetal bovine serum for $30 \mathrm{~min}$. Cells were incubated with anti-SMA in PBS at $4^{\circ} \mathrm{C}$ overnight, washed 3 times with PBS, incubated with Cy3-labeled secondary antibody (Beyotime, China) in PBS for $1 \mathrm{~h}$ at room temperature, and then analyzed using a confocal fluorescence microscope.

\section{Cardiac Fibroblast Transfection}

The sequences of the small interference RNA (siRNA) used to suppress Trim72 expression were as follows: Trim72-siRNA\#1,
5'-GCAAGAUCCUGGAGGCACATT-3'; Trim72-siRNA\#2, $5^{\prime}$-AGGCACACGUGGAGGCCAATT- $3^{\prime}$, and Trim72-siRNA\#3, 5'-AACUGAGGCAG AUGGAGAATT-3'. The control siRNA sequence was: $5^{\prime}$-UUCUCCGAACGU GUAACGUTT-3'. One day before transfection, cardiac fibroblasts were placed in $500 \mu \mathrm{l}$ growth medium without antibiotics such that they would be $60 \%$ confluent at the time of transfection. In order for each well to be transfected, siRNA duplex-Lipofectamine ${ }^{\mathrm{TM}}$ RNAiMAX complexes were prepared as per the following instructions: dilute $90 \mathrm{pmol}$ siRNA duplex in $150 \mu$ l Opti-MEM ${ }^{\circledR}$ I Reduced Serum Medium without serum; mix Lipofectamine ${ }^{\mathrm{TM}}$ RNAiMAX gently before use, and then dilute $1 \mu \mathrm{l}$ in $150 \mu \mathrm{l}$ Opti-MEM ${ }^{\circledR}$ I Reduced Serum Medium; combine the diluted siRNA duplex with the diluted Lipofectamine ${ }^{\mathrm{TM}}$ RNAiMAX; mix gently and incubate for $20 \mathrm{~min}$ at room temperature; add the siRNA duplex-Lipofectamine ${ }^{\mathrm{TM}}$ RNAiMAX complexes to each well containing cells, and incubate the cells at $37^{\circ} \mathrm{C}$ in a $\mathrm{CO}_{2}$ incubator for $24-48 \mathrm{~h}$ until assay for gene knockdown.

\section{RNA Isolation and Quantitative Real-Time PCR}

Total RNA was extracted from cultured cardiac fibroblast cells using an EZNA Total RNA Kit (Omega Bio-Tek, USA), and cDNA was generated using a PrimeScript RT Reagent Kit with a gDNA Eraser (TaKaRa, Otsu, Japan). Quantitative real-time PCR was performed using SYBR Premix ExTaq II (TLiRNaseH Plus; Ta$\mathrm{KaRa}$ ) with a CFX96 Real-Time PCR Detection System (Bio-Rad, Hercules, Calif., USA). Relative mRNA expression levels were calculated using the $2^{-\Delta \Delta \mathrm{Ct}}$ method after normalization of the expression levels of Trim72 mRNA to glyceraldehyde 3-phosphate dehydrogenase (GAPDH) mRNA.

\section{Western Blotting}

Cardiac fibroblasts were lysed with RIPA buffer (Beyotime) and boiled for $5 \mathrm{~min}$. The protein concentration of each lysate was measured using the BCA method (Beyotime). Equal quantities of protein from each cell lysate were separated on SDS-polyacrylamide electrophoresis gels and transferred to PVDF membranes (Millipore, Billerica, Mass., USA). The membranes were blocked with $5 \%$ skim milk, incubated with each primary antibody overnight at $4^{\circ} \mathrm{C}$, washed with TBS-T buffer (10 mM Tris- $\mathrm{HCl}, \mathrm{pH} 7.4$, $150 \mathrm{~mm} \mathrm{NaCl}, 0.05 \%$ Tween 20 ), and incubated with secondary antibodies. The proteins were visualized using enhanced chemiluminescence (GE Healthcare Biosciences).

\section{Microarray Assay}

Cardiac fibroblasts transfected with Trim72-si or the control were collected and the total RNA was isolated using the TRIzol reagent and subjected to microarray analysis. The microarray experiments were performed at CapitalBio Corporation using Affymetrix Rat Transcriptome Assay 1.0. To verify the microarray findings, several differentially expressed genes were further analyzed by qRT-PCR and Western blot.

\section{Migration Assay}

Transwell Boyden chambers (24-well insert, 8.0-mm; BD Biosciences) were used to determine the migration of cardiac fibroblasts. After transfection, $1 \times 10^{5}$ cells were seeded in the top chamber with the noncoated membranes. Cells were seeded in a serumfree medium and then migrated toward complete growth medium. The migrated cells were fixed with $70 \%$ methanol and stained with 
Fig. 1. siRNA reduced the expression of Trim72 in rat cardiac fibroblasts. Activated fibroblasts were identified via immunofluorescence for SMA using a phase contrast microscope (a) and a fluorescence microscope (b). c The relative levels of Trim72 mRNA expression were determined by qRT-PCR, and GAPDH was used as the control. d The effects of siRNA on Trim72 protein expression were determined via immunoblotting. $\mathrm{NC}=$ Negative control. $* \mathrm{p}<0.01$ compared to the control.
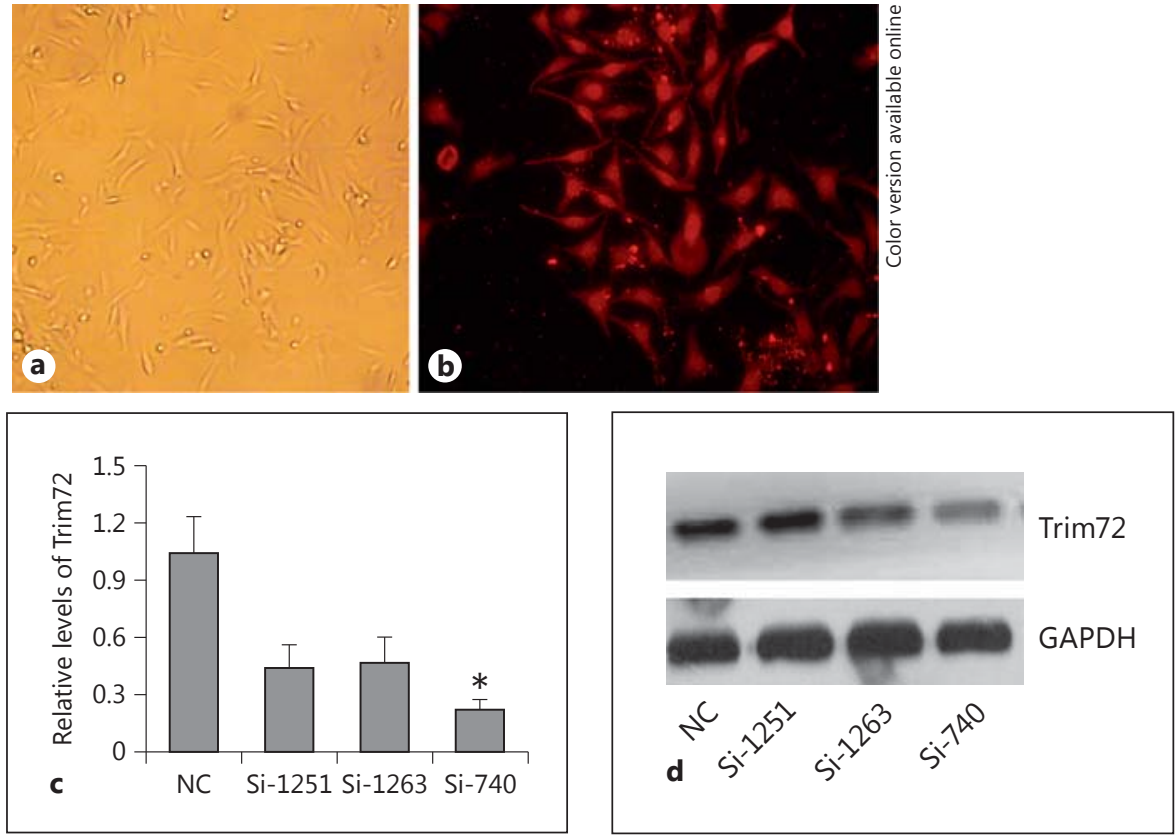

$0.5 \%$ crystal violet. Cells that migrated to the lower surface of the filters were counted in 5 random high-power fields. All experiments were carried out in triplicate.

\section{Cell Proliferation Assay}

A cell proliferation assay was performed via live cell counting using a Cell Counting Kit-8 (Dojindo, Kumamoto, Japan) as described previously [21]. For the proliferation assay, the cells were grown and transfected with siRNA after $24 \mathrm{~h}$.

\section{Statistical Analysis}

All data are presented as means \pm SD. $\mathrm{p}<0.01$ was considered statistically significant. Numerical data were calculated using Graph-Pad Prism 5.0 and analyzed using SPSS 17.0 (SPSS Inc., Chicago, Ill., USA).

\section{Results}

\section{Depletion of Trim72 in Rat Cardiac Fibroblasts}

Cardiac fibroblasts were isolated from the hearts of 2- to 3-day-old Sprague-Dawley rats by proteolytic digestion as previously described. Isolated cardiac fibroblasts were identified as activated myofibroblasts via immunofluorescence. As shown in figure 1, almost all of the isolated cells showed positive immunoreactivity with antibodies to $\alpha$-smooth muscle actin. To investigate the role of Trim72 in cardiac fibroblasts, we designed 3 siRNA targeting Trim72. After transfection with siRNA, the depletion effect of siRNA on Trim72 expression was exam- ined using qRT-PCR and immunoblot analysis. The mRNA (fig. 1a) and protein expression of Trim72 was significantly inhibited compared to the cells transfected with control siRNA.

\section{Depletion of Trim72 Suppressed the Proliferation and Migration of Rat Cardiac Fibroblasts}

To investigate the impact of Trim72 depletion on cardiac fibroblast proliferation, CCK-8 assays were carried out. In CCK-8 assays, Trim72 depletion caused significant proliferation retardation in cardiac fibroblasts both at the early time point $(24 \mathrm{~h})$ and at the late time point (48 h), whereas control siRNA did not affect the proliferation of the cells (fig. 2a). The effect of Trim72 depletion on cardiac fibroblast migration was also determined via transwell migration assay. The transwell migration assay showed that Trim72 depletion also significantly inhibited the cellular transmigration ability compared to controls (fig. 2b, c). Taken together, these data demonstrated that Triom72 knockdown resulted in cell proliferation and migration of cardiac fibroblasts.

\section{Microarray Analysis Identifies TGF- $\beta$}

\section{Pathway-Specific Signaling Downstream of Trim 72}

To gain further insight into the potential molecular mechanism underlying the Trim72 knockdown-induced suppression of the proliferation and migration of cardiac fibroblasts, we tested a gene expression profile microar- 
Fig. 2. Silencing of Trim72 decreased the proliferation and migration of cardiac fibroblasts. a After transfection of the cardiac fibroblasts with siRNA for $24 \mathrm{~h}$, a cellcounting assay was performed using the Cell Counting Kit-8. The normalized proliferation levels relative to the control siRNA are shown as means \pm SD. ${ }^{*} \mathrm{p}<0.01$ compared to the control. b Cell migration was determined using a transwell chamber migration assay; $1 \times 10^{5}$ cells transfected with siRNA were added in the upper chamber. After $24 \mathrm{~h}$, representative pictures showed migrated cardiac fibroblasts stained with crystal violet. c The migratedcell numbers normalized relative to the control are shown as means \pm SD. ${ }^{*} \mathrm{p}<0.01$ compared to the control. All of the data are from 3 independent experiments $(n=3)$. $\mathrm{NC}=$ Negative control.
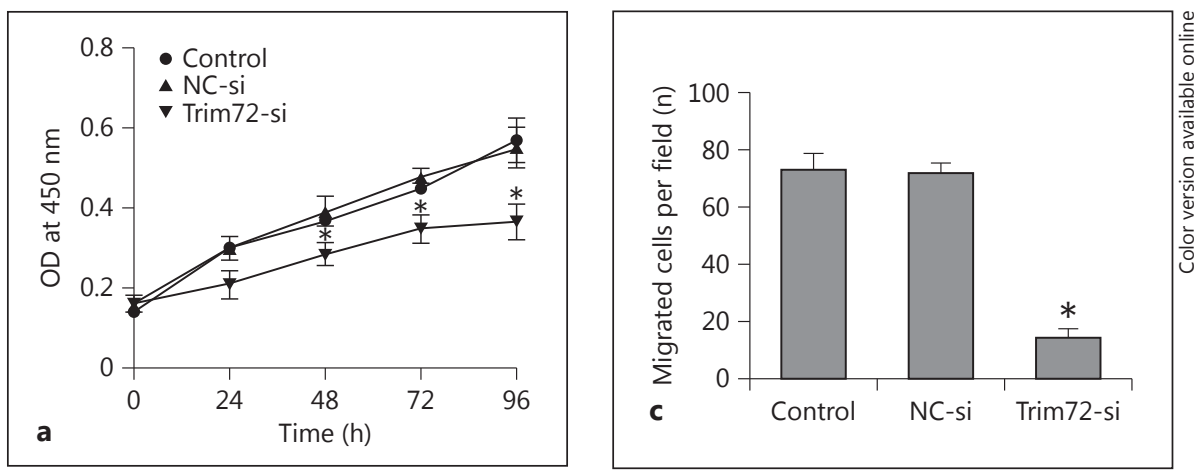

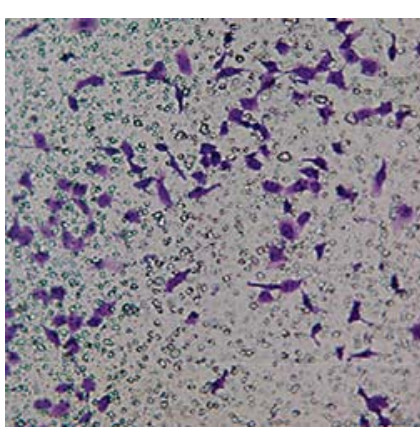

b Control

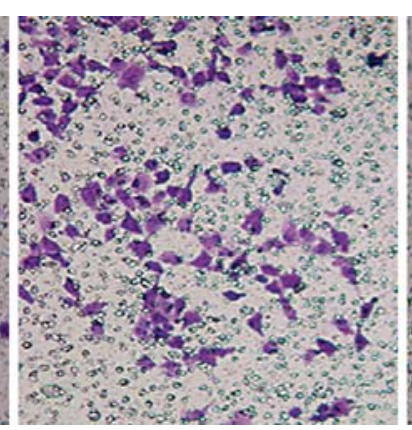

NC-si

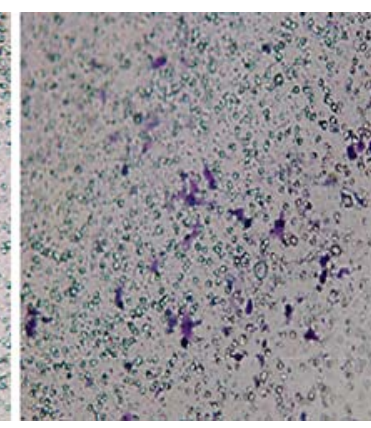

Trim72-si ray assay to compare differential gene expression profiles between Trim 72 depletion and negative control cardiac fibroblasts. Gene expression profiling revealed that 123 genes were upregulated (ratio >2.0) and 142 genes were downregulated (ratio, <0.5). Using the Kyoto Encyclopedia of Genes and Genomes, and Pathway Profiler analysis, the significant signaling pathways were categorized into different groups including the TGF- $\beta$ signaling pathway and cell cycle regulation, among others. Important genes and pathways involved in this process are shown in figure $3 \mathrm{a}$ and $\mathrm{b}$. QRT-PCR and Western blot demonstrated that Trim72 depletion caused the expression levels of TGF- $\beta_{1}$ and TGF $\beta$ RI to decrease (fig. 3c, d). Overall, this data analysis showed that Trim72 regulates migration and proliferation via the TGF- $\beta$ signaling pathway.

\section{Discussion}

Cardiovascular diseases are the leading cause of death worldwide [22]. In response to diverse stimuli, cardiac fibroblasts proliferate, migrate, and excrete ECM to maintain myocardial function. ECM metabolic imbalance is involved in various cardiovascular diseases such as myocardial infarction, heart failure, and atrial fibrillation, which may lead to cardiac remodeling [23-25]. Account- ing for two thirds of the cells in human heart, cardiac fibroblasts are the most important cell type and have various functions in both ECM metabolism and cardiac fibroblast proliferation, which plays an important role in cardiac remodeling $[26,27]$. Cardiac fibrosis is regulated by a multi-step and highly complex network of interacting genes and proteins.

It has been shown that in skeletal muscle cells breakage of the plasma membrane causes overexpression of Trim 72 at the injury site, accompanied by a reduced extracellular dye penetration into the cell, suggesting the formation of a repair patch by Trim $72[28,29]$. The tripartite motif proteins are large and display diverse cell biological functions. Previous studies have shown that Trim protein function is related to several human diseases, including cancer and muscular dystrophy. To investigate the cell-molecular mechanisms of Trim proteins, studies have focused on the role of various protein motifs in mediating intracellular signaling events. Similar to other Trim family members, the molecular mechanism of Trim72 has not yet been extensively studied in cardiac fibroblasts [30, 31].

In the present study, we used siRNA to knock down Trim72 and then investigated the impact of Trim72 on cardiac fibroblast proliferation and migration. We found that Trim 72 depletion significantly decreased the proliferation and migration of cardiac fibroblasts. Further- 


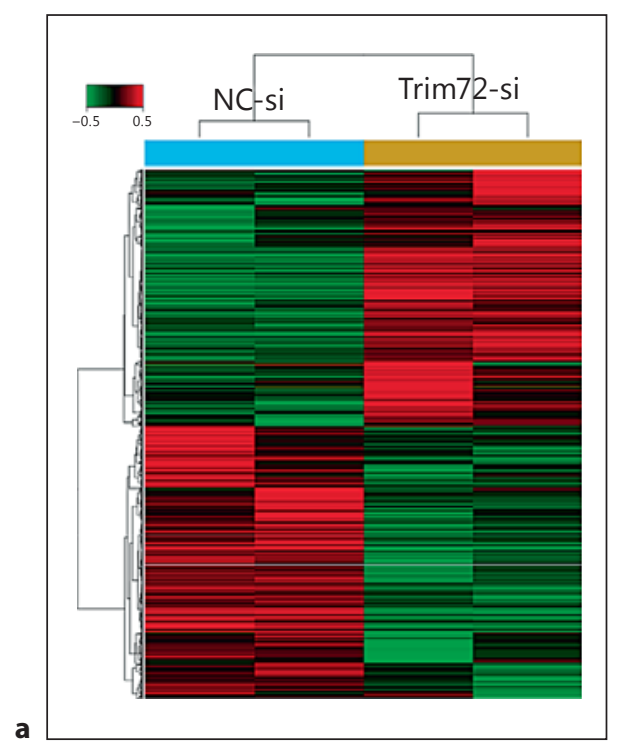

\begin{tabular}{|c|c|c|c|c|}
\hline \multicolumn{5}{|c|}{ Important pathways affected by Trim72 knockdown } \\
\hline Pathway name & Database & Gene & $\mathrm{p}$ value & $\mathrm{Q}$ value \\
\hline \multirow{3}{*}{$\begin{array}{l}\text { TGF- } \beta \\
\text { signaling } \\
\text { pathway }\end{array}$} & KEGG & 11 & $2.16 \times 10^{-11}$ & $2.3 \times 10^{-7}$ \\
\hline & BioCarta & 3 & 0.0001227 & 0.000425 \\
\hline & GenMAPP & 6 & $6.37 \times 10^{-5}$ & $9.95 \times 10^{-6}$ \\
\hline \multirow[t]{3}{*}{ Cell cycle } & KEGG & 3 & 0.1463492 & 0.001389 \\
\hline & BioCarta & 3 & 0.0013522 & 0.000526 \\
\hline & GenMAPP & 7 & 0.0086602 & 0.0025602 \\
\hline \multirow{3}{*}{$\begin{array}{l}\text { ECM-receptor } \\
\text { interaction }\end{array}$} & KEGG & 5 & 0.0328549 & 0.008635 \\
\hline & BioCarta & 3 & 0.0062454 & 0.000835 \\
\hline & GenMAPP & 2 & 0.0172452 & 0.012743 \\
\hline \multirow{3}{*}{$\begin{array}{l}\text { Wnt/catenin } \\
\text { signaling } \\
\text { pathway }\end{array}$} & KEGG & 3 & 0.019831 & 0.0033153 \\
\hline & BioCarta & 2 & 0.096241 & 0.0161427 \\
\hline & GenMAPP & 2 & 0.0028352 & 0.00216389 \\
\hline
\end{tabular}
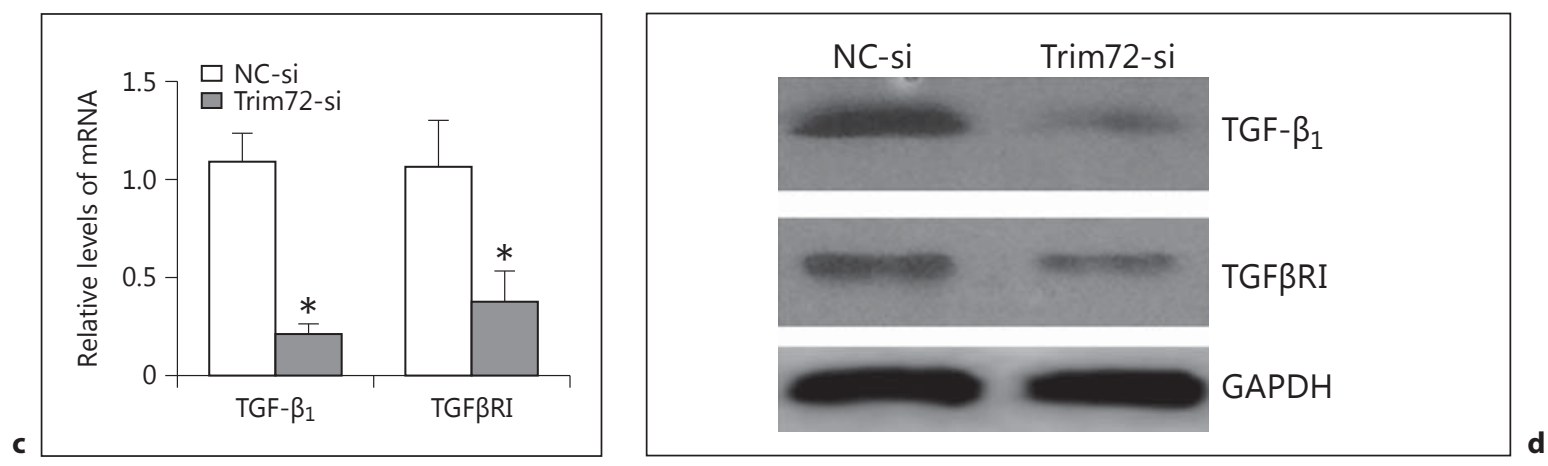

Fig. 3. Microarray analysis and validation of Trim72 via the TGF- $\beta$ signaling pathway. a, b Microarray-based gene expression profiling and important pathways affected by Trim72 depletion. $\mathbf{c}$, d The expression levels of TGF- $\beta_{1}$ and TGF $\beta$ RI were determined by qRT-PCR and immunoblotting in rat cardiac fibroblasts. ${ }^{*} \mathrm{p}<0.01$ compared to the control. $\mathrm{NC}=$ Negative control.

more, using gene expression profile microarray analysis, we have found that Trim72 depletion could result in downregulation of the TGF- $\beta$ signaling pathway, suggesting that Trim 72 regulates the proliferation and migration of cardiac fibroblasts through the TGF- $\beta$ signaling pathway. Our study is consistent with previous studies that found that overexpression of myocardial TRIM72 could induce diabetic and other cardiomyopathies [29, 32-35]. However, other pathways such as angiotensin, endothelin, connective tissue growth factor (CCCN2), and platelet-derived growth factor may also be involved in the proliferation of cardiac fibroblasts. The Toll/Il-1 receptor domain-containing adaptor-inducing IFN- $\beta$ (TRIF) may promote atrial fibrosis via microphages [36-38]. Rivaroxaban has been reported to inhibit AngII-stimulated cardiac fibrosis through nuclear factor- $\mathrm{kB}$ and the mito- gen-activated protein kinase pathway [39-41]. To the best of our knowledge, the present study has, for the first time, shown that Trim72 can regulate the migration of cardiac fibroblasts. Further clinical studies are needed to confirm this observation.

In summary, our study demonstrates that Trim72 might play a pivotal role in the proliferation of neonatal rat cardiac fibroblasts, which could be a potential target for the treatment of cardiac fibrosis. However, the involvement of other signaling pathways and factors in the formation of cardiac fibrosis cannot be excluded.

\section{Conflict of Interest}

There is no potential conflict of interests to disclose. 


\section{References}

1 Sun G, Xue R, Yao F, Liu D, Huang H, Chen C, Li Y, Zeng J, Zhang G, Dong Y, Liu C: The critical role of sestrin 1 in regulating the proliferation of cardiac fibroblasts. Arch Biochem Biophys 2014;542:1-6.

2 Tank J, Lindner D, Wang X, Stroux A, Gilke L, Gast M, Zietsch C, Skurk C, Scheibenbogen C, Klingel K, Lassner D, Kuhl U, Schultheiss HP, Westermann D, Poller W: Single-target RNA interference for the blockade of multiple interacting proinflammatory and profibrotic pathways in cardiac fibroblasts. J Mol Cell Cardiol 2014;66:141-156.

3 Zhao X, Wang K, Liao Y, Zeng Q, Li Y, Hu F, Liu Y, Meng K, Qian C, Zhang Q, Guan H, Feng K, Zhou Y, Du Y, Chen Z: MicroRNA101a inhibits cardiac fibrosis induced by hypoxia via targeting TGFbetaRI on cardiac fibroblasts. Cell Physiol Biochem 2015;35:213226.

4 Wang L, Chen Q, Li G, Ke D: Ghrelin stimulates angiogenesis via GHSR1a-dependent MEK/ERK and PI3K/Akt signal pathways in rat cardiac microvascular endothelial cells. Peptides 2012;33:92-100.

5 Okada M, Oba Y, Yamawaki H: Endostatin stimulates proliferation and migration of adult rat cardiac fibroblasts through PI3K/ Akt pathway. Eur J Pharmacol 2015;750:2026.

6 Bayorh MA, Eatman D, Walton M, Socci RR, Thierry-Palmer M, Emmett N: 1A-779 attenuates angiotensin-(1-7) depressor response in salt-induced hypertensive rats. Peptides 2002;23:57-64.

7 Chung ES, Miller L, Patel AN, Anderson RD, Mendelsohn FO, Traverse J, Silver KH, Shin J, Ewald G, Farr MJ, Anwaruddin S, Plat F, Fisher SJ, AuWerter AT, Pastore JM, Aras R, Penn MS: Changes in ventricular remodelling and clinical status during the year following a single administration of stromal cell-derived factor-1 non-viral gene therapy in chronic ischaemic heart failure patients: the STOPHF randomized phase II trial. Eur Heart J 2015;36:2228-2238.

8 Watson CJ, Horgan S, Neary R, Glezeva N, Tea I, Corrigan N, McDonald K, Ledwidge M, Baugh J: Epigenetic therapy for the treatment of hypertension-induced cardiac hypertrophy and fibrosis. J Cardiovasc Pharmacol Ther 2016;21:127-137.

9 Cai C, Masumiya H, Weisleder N, Pan Z, Nishi M, Komazaki S, Takeshima H, Ma J: MG53 regulates membrane budding and exocytosis in muscle cells. J Biol Chem 2009;284: 3314-3322.

10 Kim SC, Kellett T, Wang S, Nishi M, Nagre N, Zhou B, Flodby P, Shilo K, Ghadiali SN, Takeshima H, Hubmayr RD, Zhao X: TRIM72 is required for effective repair of alveolar epithelial cell wounding. Am J Physiol Lung Cell Mol Physiol 2014;307:L449-L459.
11 Ohno Y, Sugiura T, Ohira Y, Yoshioka T, Goto K: Loading-associated expression of TRIM72 and caveolin-3 in antigravitational soleus muscle in mice. Physiol Rep 2014;2.

12 Cai C, Masumiya H, Weisleder N, Matsuda N, Nishi M, Hwang M, Ko JK, Lin P, Thornton A, Zhao X, Pan Z, Komazaki S, Brotto M, Takeshima H, Ma J: MG53 nucleates assembly of cell membrane repair machinery. Nat Cell Biol 2009; 11:56-64.

13 Hwang M, Ko JK, Weisleder N, Takeshima H, Ma J: Redox-dependent oligomerization through a leucine zipper motif is essential for MG53-mediated cell membrane repair. Am J Physiol Cell Physiol 2011;301:C106-C114.

14 McNeil PL, Kirchhausen T: An emergency response team for membrane repair. Nat Rev Mol Cell Biol 2005;6:499-505.

15 Cao CM, Zhang Y, Weisleder N, Ferrante C, Wang X, Lv F, Zhang Y, Song R, Hwang M, Jin L, Guo J, Peng W, Li G, Nishi M, Takeshima H, Ma J, Xiao RP: MG53 constitutes a primary determinant of cardiac ischemic preconditioning. Circulation 2010;121:2565-2574.

16 Wang X, Xie W, Zhang Y, Lin P, Han L, Han P, Wang Y, Chen Z, Ji G, Zheng M, Weisleder N, Xiao RP, Takeshima H, Ma J, Cheng H: Cardioprotection of ischemia/reperfusion injury by cholesterol-dependent MG53-mediated membrane repair. Circ Res 2010;107: 76-83.

17 Weisleder N, Takizawa N, Lin P, Wang X, Cao C, Zhang Y, Tan T, Ferrante C, Zhu H, Chen PJ, Yan R, Sterling M, Zhao X, Hwang M, Takeshima M, Cai C, Cheng H, Takeshima H, Xiao RP, Ma J: Recombinant MG53 protein modulates therapeutic cell membrane repair in treatment of muscular dystrophy. Sci Transl Med 2012;4:139ra185.

18 Zhang Y, Lv F, Jin L, Peng W, Song R, Ma J, Cao CM, Xiao RP: MG53 participates in ischaemic postconditioning through the RISK signalling pathway. Cardiovasc Res 2011;91: 108-115.

19 Köhncke C, Lisewski U, Schleussner L, Gaertner C, Reichert S, Roepke TK: Isolation and $\mathrm{Kv}$ channel recordings in murine atrial and ventricular cardiomyocytes. J Vis Exp 2013; e50145.

20 Mitchell MD, Laird RE, Brown RD, Long CS: IL-1beta stimulates rat cardiac fibroblast migration via MAP kinase pathways. Am J Physiol Heart Circ Physiol 2007;292:H1139H1147.

21 Yan HX, Wang HY, Zhang R, Chen L, Li BA, Liu SQ, Cao HF, Qiu XH, Shan YF, Yan ZH, Wu HP, Tan YX, Wu MC: Negative regulation of hepatocellular carcinoma cell growth by signal regulatory protein alpha1. Hepatology 2004;40:618-628.

22 Pandya A, Sy S, Cho S, Weinstein MC, Gaziano TA: Cost-effectiveness of 10-year risk thresholds for initiation of statin therapy for primary prevention of cardiovascular disease. JAMA 2015;314:142-150.
23 Woitek F, Zentilin L, Hoffman NE, Powers JC, Ottiger I, Parikh S, Kulczycki AM, Hurst M, Ring N, Wang T, Shaikh F, Gross P, Singh H, Kolpakov MA, Linke A, Houser SR, Rizzo V, Sabri A, Madesh M, Giacca M, Recchia FA: Intracoronary cytoprotective gene therapy: a study of VEGF-B167 in a pre-clinical animal model of dilated cardiomyopathy. J Am Coll Cardiol 2015;66:139-153.

24 Zhang M, Prosser BL, Bamboye MA, Gondim AN, Santos CX, Martin D, Ghigo A, Perino A, Brewer AC, Ward CW, Hirsch E, Lederer WJ, Shah AM: Contractile function during angiotensin-II activation: increased Nox2 activity modulates cardiac calcium handling via phospholamban phosphorylation. J Am Coll Cardiol 2015;66:261-272.

25 Stone GW, Adams DH, Abraham WT, Kappetein AP, Généreux P, Vranckx P, Mehran R, Kuck KH, Leon MB, Piazza N, Head SJ, Filippatos G, Vahanian AS; Mitral Valve Academic Research Consortium: Clinical trial design principles and endpoint definitions for transcatheter mitral valve repair and replacement. 2. Endpoint definitions: consensus document from the Mitral Valve Academic Research Consortium. J Am Coll Cardiol 2015;66:308321.

26 Huber RJ, O’Day DH: Proteomic profiling of the extracellular matrix (slime sheath) of Dictyostelium discoideum. Proteomics 2015;15: 3315-3319.

27 Naba A, Clauser KR, Ding H, Whittaker CA, Carr SA, Hynes RO: The extracellular matrix: tools and insights for the 'omics' era. Matrix Biol2015,DOI: 10.1016/j.matbio.2015.06.003.

28 Duann P, Li H, Lin P, Tan T, Wang Z, Chen K, Zhou X, Gumpper K, Zhu H, Ludwig T, Mohler PJ, Rovin B, Abraham WT, Zeng C, Ma J: MG53-mediated cell membrane repair protects against acute kidney injury. Sci Transl Med 2015;7:279ra236.

29 Liu F, Song R, Feng Y, Guo J, Chen Y, Zhang Y, Chen T, Wang Y, Huang Y, Li CY, Cao C, Zhang Y, Hu X, Xiao RP: Upregulation of MG53 induces diabetic cardiomyopathy through transcriptional activation of peroxisome proliferation-activated receptor $\alpha$. Circulation 2015;131:795-804.

30 Liu J, Zhu H, Zheng Y, Xu Z, Li L, Tan T, Park $\mathrm{KH}$, Hou J, Zhang C, Li D, Li R, Liu Z, Weisleder N, Zhu D, Lin P, Ma J: Cardioprotection of recombinant human MG53 protein in a porcine model of ischemia and reperfusion injury. J Mol Cell Cardiol 2015;80:10-19.

31 Ma H, Liu J, Bian Z, Cui Y, Zhou X, Zhou X, Zhang B, Adesanya TM, Yi F, Park KH, Tan $\mathrm{T}$, Chen Z, Zhu H: Effect of metabolic syndrome on mitsugumin 53 expression and function. PLoS One 2015;10:e0124128.

32 Ham YM, Mahoney SJ: Compensation of the AKT signaling by ERK signaling in transgenic mice hearts overexpressing TRIM72. Exp Cell Res 2013;319:1451-1462.
Trim72 Regulates the Proliferation and Migration of Rat Cardiac Fibroblasts 
33 Liu S, Xu SW, Kennedy L, Pala D, Chen Y, Eastwood M, Carter DE, Black CM, Abraham DJ, Leask A: FAK is required for TGFbetainduced JNK phosphorylation in fibroblasts: implications for acquisition of a matrix-remodeling phenotype. Mol Biol Cell 2007;18: 2169-2178.

34 Schneeweiss S, Patrick AR, Maclure M, Dormuth CR, Glynn RJ: Adherence to statin therapy under drug cost sharing in patients with and without acute myocardial infarction: a population-based natural experiment. Circulation 2007;115:2128-2135.

35 Kimura S, Egashira K, Chen L, Nakano K, Iwata $\mathrm{E}$, Miyagawa $\mathrm{M}$, Tsujimoto $\mathrm{H}, \mathrm{Hara} \mathrm{K}$, Morishita R, Sueishi K, Tominaga R, Sunagawa K: Nanoparticle-mediated delivery of nuclear factor kappaB decoy into lungs ameliorates monocrotaline-induced pulmonary arterial hypertension. Hypertension 2009;53: 877-883.
36 Rodríguez-Vita J, Sánchez-López E, Esteban V, Rupérez M, Egido J, Ruiz-Ortega M: Angiotensin II activates the Smad pathway in vascular smooth muscle cells by a transforming growth factor-beta-independent mechanism. Circulation 2005;111:2509-2517.

37 Liao CH, Akazawa H, Tamagawa M, Ito K, Yasuda N, Kudo Y, Yamamoto R, Ozasa Y, Fujimoto M, Wang P, Nakauchi H, Nakaya H, Komuro: Cardiac mast cells cause atrial fibrillation through PDGF-A-mediated fibrosis in pressure-overloaded mouse hearts. J Clin Invest 2010;120:242-253

38 Chen XQ, Zhang DL, Zhang MJ, Guo M, Zhan YY, Liu F, Jiang WF, Zhou L, Zhao L, Wang QX, Liu X: TRIF promotes angiotensin II-induced cross-talk between fibroblasts and macrophages in atrial fibrosis. Biochem Biophys Res Commun 2015;464:100-105.
39 Hashikata T, Yamaoka-Tojo M, Namba S, Kitasato L, Kameda R, Murakami M, Niwano H, Shimohama T, Tojo T, Ako J: Rivaroxaban Inhibits Angiotensin II-Induced Activation in Cultured Mouse Cardiac Fibroblasts Through the Modulation of NF- $\mathrm{kB}$ Pathway. Int Heart J 2015;56:544-550.

40 Kowala MC, Murugesan N, Tellew J, Carlson K, Monshizadegan H, Ryan C, Gu Z, Kane B, Fadnis L, Baska RA, Beyer S, Arthur S, Dickinson $\mathrm{K}$, Zhang D, Perrone M, Ferrer $\mathrm{P}$, Giancarli M, Baumann J, Bird E, Panchal B, Yang Y, Trippodo N, Barrish J, Macor JE: Novel dual action AT1 and ETA receptor antagonists reduce blood pressure in experimental hypertension. J Pharmacol Exp Ther 2004;309:275-284.

41 Panek AN, Posch MG, Alenina N, Ghadge SK, Erdmann B, Popova E, Perrot A, Geier C, Morano RDI, Bader M, Özcelik C: Connective tissue growth factor overexpression in cardiomyocytes promotes cardiac hypertrophy and protection against pressure overload. PLoS One 2009;4:e6743. 